\title{
Airway inflammation in COPD: physiological outcome measures and induced sputum
}

\author{
R.O. Crapo*, R.L. Jensen*, F.E. Hargreave ${ }^{\#}$
}

Airway inflammation in COPD: physiological outcome measures and induced sputum. R.O. Crapo, R.L. Jensen, F.E. Hargreave. C ERS Journals Ltd 2003.

ABSTRACT: Chronic obstructive pulmonary disease (COPD) is a result of airway inflammation, and the best predictor of COPD is the early detection of airflow limitation by spirometry. The Global Initiative for Obstructive Lung Disease Workshop Report defines airflow limitation using simple spirometric indices. Available guidelines categorise the severity of COPD using forced expiratory volume in one second (FEV1) and forced vital capacity (FVC), with symptoms playing a minor role in the assessment.

Current standards define COPD by progressive loss of FEV1, and thus longitudinal decline in FEV1 will be the primary outcome variable for intervention studies aimed at preventing or reducing the loss of pulmonary function. There is evidence, however, that the variable FEV1/FVC and FEV1 are often not measured properly in all settings.

This article will discuss the roles of physiological measurements in diagnosing COPD and physiological outcome measures for COPD. It does not formally compare physiological measures with other outcome measures, such as symptoms or quality of life. Additionally, improved treatment of established disease requires a better understanding of the inflammatory process and its clinical effects and treatment.

The inflammatory process, and how drugs affect it, can be studied noninvasively or relatively noninvasively by using refined methods of examining spontaneous or induced sputum. Enhanced understanding of the use of induced sputum will assist in predicting patients' responses to short- and long-term inhaled corticosteroid treatment, and the methods of sputum examination need to be simplified so that they can be applied more easily to clinical practice.

Eur Respir J 2003; 21: Suppl. 41, 19s-28s.
*Pulmonary Division, LDS Hospital and University of Utah, Salt Lake City, UT, USA. ${ }^{\#}$ Firestone Institute for Respiratory Health and McMaster University, Hamilton, ON, Canada.

Correspondence: R.O. Crapo

Pulmonary Division

LDS Hospital

8th Avenue and C Street

Salt Lake City

UT 84143

USA

Fax: 18014081671

E-mail: Ldrcrapo@ihc.com

Keywords: Airflow

chronic obstructive pulmonary disease

markers of airway inflammation

pulmonary function

sputum induction

Received: August 212002

Accepted after revision: February 202003
Chronic obstructive pulmonary disease (COPD) is defined by the Global Initiative for Obstructive Lung Disease (GOLD) as a "disease state characterised by airflow limitation that is not fully reversible. ... The airflow limitation is usually both progressive and associated with an abnormal inflammatory response of the lungs to noxious particles or gases" [1]. The absence of reversibility tends to exclude asthma by definition, although asthma can coexist with COPD.

\section{Methods of assessing airflow limitation: current recommendations and their limitations}

Available guidelines categorise the severity of COPD primarily by using forced expiratory volume in one second (FEV1), whereas symptoms play a minor role in the assessment [1-5]. This tight link between FEV1 and COPD reflects the fact that spirometry is the standard for defining the presence of airway obstruction and the progressive loss of FEV1, the physiological variable that characterises COPD severity and predicts its mortality. Spirometry has become the standard, in part, because good quality and inexpensive tests are widely available.

The GOLD Workshop Report explicitly defines airflow limitation using simple spirometric indices. Specifically, airflow limitation is defined as an FEV1/forced vital capacity (FVC) $<70 \%$ and a postbronchodilator FEV1 $<80 \%$ of predicted [1]. The GOLD Workshop report acknowledges that these criteria need clinical validation. The GOLD criteria avoid the need to calculate a lower limit of the "normal" range for FEV1, but predicted values have to be calculated for FEV1. In contrast, the American Thoracic Society's (ATS) interpretative standards document recommends using a statistically defined lower limit of normal for the FEV1/FVC ratio as the primary variable to diagnose the presence of airway obstruction. Both guidelines use FEV1, expressed as per cent predicted, to categorise the severity of obstruction $[1,6]$. The GOLD guidelines specify the use of the postbronchodilator FEV1.

Current standards define COPD by progressive loss of FEV1 and thus longitudinal decline in FEV1 will be the primary outcome variable for intervention studies aimed at preventing or reducing the loss of pulmonary function.

The use of FEV1/FVC and FEV1 to diagnose, prevent and treat COPD is not without problems. Although there is no doubt that these variables can be measured accurately and precisely, there is also good evidence that they are often not properly measured in all settings. In research settings where critical oversight is provided, test quality is maintained at a high level. It is common for ATS acceptability and reproducibility criteria to be met $>90 \%$ of the time in both healthy individuals and those with respiratory diseases [7-9]. In settings without such training and oversight, however, such as primarycare offices, good test performance is less consistent. For example, spirometry was introduced into 30 randomly selected New Zealand primary-care practices for 16 weeks [10]. Onehalf of the office staff received two brief, formal-training 
sessions in spirometry; the others received no formal training. In the trained group, $33.1 \%$ of the patient tests showed two acceptable tracings; in the untrained group that number was $12.5 \%$. The interpretations of the primary-care physicians were judged to be correct in only $53 \%$ of cases.

Good initial technician training and regular feedback to technicians are essential elements to maintaining good test quality in research settings and these practices should also work in clinical laboratories [8]. Software developed for research studies allows spirometry quality to be assessed rapidly and electronic feedback quickly returned to the technicians performing the tests [11]. These quality control techniques can be instituted in clinical laboratories. With good quality control, it is reasonable to expect that clinical pulmonary function laboratories should meet ATS quality standards $\geqslant 80 \%$ of the time.

A good quality test is a necessary precondition for adequate interpretation, but it is not sufficient. One significant unsolved problem is that the interpretation of spirometry as "normal" or "abnormal" is based on univariate dichotomous comparisons with reference values derived from healthy persons. Lower limits of the healthy subject range (normal range) are treated as absolute demarcations of normal or abnormal. This is particularly problematic for COPD in that it is a condition defined by spirometry with no independent means of making the diagnosis. The true sensitivity and specificity of current categorisations is unknown.

A second potential problem arises when very simple strategies, such as those proposed by the GOLD initiative, are used to diagnose airway obstruction. For example, defining airflow obstruction as an $\mathrm{FEV} 1 / \mathrm{FVC}$ ratio $<70 \%$ (with or without an additional requirement that FEV1 be $<80 \%$ pred) has a significant potential for false-positive results. A fixed $70 \%$ criterion for the $\mathrm{FEV} 1 / \mathrm{FVC}$ ratio ignores the known decline of elastic recoil with age. The statistical lower limit of the healthy reference sample for FEV1/FVC crosses below $70 \%$ at $\sim 40$ yrs for males (fig. 1) and at 45 yrs for females [12]. Using a simple cut-off means some healthy older patients will have an FEV1/FVC ratio $<0.7$ and be classified falsely as having airflow obstruction (a false-positive result). This problem is reduced but not eliminated if slow

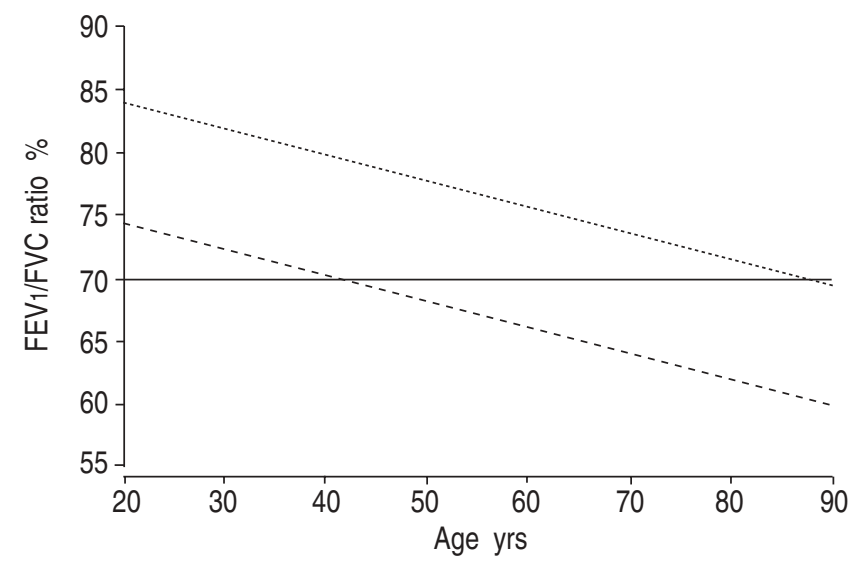

Fig. 1.-The third National Health and Nutrition Examination Survey spirometry reference values show the potential errors in using a fixed forced expiratory volume in one second (FEV1)/forced vital capacity (FVC) ratio of $70 \%$ (solid line) to define the presence of airway obstruction. After age 41 yrs in Caucasian males, the statistically derived lower limit of the "normal" range falls below $70 \%$. The potential for false-positive categorisations then increases with age. In females, the statistically derived lower limit of normal falls below $70 \%$ at $\sim 45 \mathrm{yrs}$. .......... predicted male FEV1/FVC; - - -: lower limit of normal for male FEV1/FVC. Data from [12]. vital capacity (SVC) is used instead of FVC. Using a criterion of FEV1 $<80 \%$ pred also results in misclassifications. A combination of FEV1/FVC and FEV1 per cent predicted criteria for defining COPD should reduce misclassifications, but again, there is no independent means of diagnosis and the performance remains unknown. The potential for significant false-positive results is real, and misdiagnosing individuals as either having or not having COPD can lead to errors in studies and in clinical care.

\section{FEV6 and FEV1/FEV6 as alternatives for diagnosing chronic obstructive pulmonary disease}

Average FEV1/FVC declines both with age and the duration of the expiratory effort, and thus there is a potential for discontinuity between predicted values created using one set of average expiratory times and clinical measurements that may have significantly different expiratory times.

For older persons, an FVC manoeuvre can be uncomfortable, even distressing, as expiratory times stretch out as long as $15-20 \mathrm{~s}$. These extended expiratory times may be associated with increased risk of syncope. When technicians push patients towards an expiratory plateau, expiratory times increase as people age and then tend to decrease in older, more frail, individuals. Such changes can create an interpretative problem. A difference between the reference and measured values will lead to errors in interpretation. For example, if the reference study has an average expiratory time of $8 \mathrm{~s}$ and the clinical test for a patient has an expiratory time of $15 \mathrm{~s}$, the patient will more likely be called obstructed (as expiratory time increases, FVC increases and FEV1/FVC declines).

These issues, as well as that of simplifying spirometry, have led to an interest in surrogates for FVC, including shorter expiratory times as a fixed expiratory end-point. Reference equations based on the third National Health and Nutrition Examination Survey (NHANES III) study include both FEV1/FVC and FEV1/forced expiratory volume in six seconds (FEV6) ratios [12]. The ATS spirometry standards (1995) define an acceptable duration of exhalation as $\geqslant 6 \mathrm{~s}$ or the presence of a plateau [13], thus FEV6 is an attractive surrogate for FVC. The NHANES III developed spirometric reference values for three ethnic groups, and their spirometry reference equations show FEV1/FEV6 to have a slower decline with age than FEV1/FVC [12], which is consistent with theoretical fears about the interactions between age and expiratory time for FVC.

A few studies have addressed the performance of FEV6 as an FVC surrogate. In comparison with FEV1/FVC, the FEV1/ FEV6 ratio was found to be relatively independent of ethnic group [12]. A study in 502 consecutive patients in Christchurch, New Zealand, demonstrated that the FEV1/FEV6 ratio performed as well as FEV1/FVC in diagnosing airflow obstruction [14]. The sensitivity and specificity of FEV1/FEV6 for obstruction defined by FEV1/FVC were 99.5 and $100 \%$, respectively, after allowing for a possible $100 \mathrm{~mL}$ error in FEV1 and FEV6. The FEV6 was $\sim 25 \%$ less variable than FVC. The variability of timed expiratory volumes is, at its minimum, between 6-7 s and FEV6 can be estimated from expiratory times as short as $3 \mathrm{~s}$ [15]. These attributes make the FEV1/FEV6 ratio an attractive surrogate for the FEV1/FVC. Simplifying spirometry testing may also facilitate its move into primary-care settings. The FEV1/FEV6 ratio is not yet widely available on commercial spirometers, however, and the only reference values are those of the NHANES III [12]. 


\section{Alternatives for diagnosing airway obstruction}

Alternatives to FEV1/FVC for diagnosing airway obstruction include peak expiratory flow, forced oscillation techniques, expiratory time on physical examination and the mid- and instantaneous flows from spirometry. All of these have practical problems, and as yet, none have achieved a level of acceptance in clinical practice.

Peak flow, especially measured with peak-flow meters, has not been found to perform comparably with FEV1 in diagnosing and categorising COPD [16]. Peak flow is more effort-dependent than FEV1 and peak-flow meters have significant interinstrument variability. The mid-flows have not definitively been shown to have advantages over FVC and FEV1. They also have relatively high interindividual and intraindividual variability.

Forced oscillation techniques offer an attractive option because they require little patient effort and cooperation. Although modern technology has made this test easier to perform, the technique has not yet been established in the clinical setting [17]. There are no well-established reference values and no clinically validated, simple-to-use, interpretative schemes available for it.

\section{Outcomes}

The role of physiological testing after the diagnosis of COPD has been established and shifts with the questions being asked. Maximally forced expiratory flow volume (MEFV) parameters requiring a full inspiration prior to the manoeuvre (e.g. FVC, FEV1) are well established in diagnosing COPD and evaluating its severity and prognosis $[1,18]$. In studies of therapies that may impact the accelerated loss of pulmonary function, FEV1 is the primary spirometric outcome variable. Smoking cessation is the only therapy known to alter the rate of decline in FEV1 in COPD. Four major trials have demonstrated that inhaled corticosteroids do not change the rate of pulmonary function loss in COPD, although they may provide benefit to some patients in reducing the number of exacerbations, slowing the rate of decline in quality of life and reducing office visits [19]. Other therapies targeting the underlying inflammatory process are in development.

In the absence of a therapy that affects the fundamental disease process, the focus of therapy (and outcome variables) shifts to improving patients' quality of life. Methods of ascertaining quality of life include assessing symptoms and ability to function, as well as taking formal measures [20, 21]. In this setting, the traditional MEFV parameters tend to perform poorly as outcome measures. For example, FEV1 correlates poorly to symptoms such as dyspnoea, measures of health-related quality of life and exercise performance [18, 22, 23]. In severe emphysema, some patients exhibit an isolated bronchodilator response where they may respond with FVC but not with FEV1 [24].

Other physiological outcome variables have been proposed based on a better understanding of the mechanisms of dyspnoea and symptomatic improvement in response to bronchodilator therapy. Patients with COPD, especially those with more advanced obstruction, are likely to have flow limitation during quiet breathing. This flow limitation leads to dynamic hyperinflation of the lungs that is present at rest and worsens with exercise as respiratory rate and flows increase $[18,22,23,25]$. Dyspnoea increases with the degree of hyperinflation and decreases with therapies that reduce hyperinflation [18, 26-28]. Treatment of severe COPD with both albuterol and ipratropium bromide results in less dyspnoea at rest and exercise and improved exercise performance. These symptomatic improvements are associated with decreases in functional residual capacity (FRC) and residual volume (RV) and with increases in FVC, SVC, inspiratory capacity (IC) and specific conductance. RV was the most frequently reduced lung volume [18, 22, 25, 29-31]. The decrease in FRC means that end-expiratory lung volume decreased and that tidal breathing had moved to a lower operational lung volume. Such data suggest that FRC and $\mathrm{RV}$ would be useful outcome measures in COPD. Since they are nondisplaceable lung volumes, they cannot be measured with a spirometer and the equipment required to measure them is relatively sophisticated and expensive. Fortunately, increases in IC and SVC reasonably reflect the lung volume response to a bronchodilator and can be used to infer the decrease in end-expiratory lung volume [18, 22, 30, 32]. Changes in IC were larger and more frequent than changes in vital capacity, and SVC worked better than FVC [22]. Maximum exercise studies found that only IC correlated with maximum work in asthma and COPD $\left(r^{2}=0.66\right)$ [33]. Figure 2 illustrates the effect of albuterol on IC in a COPD patient. After albuterol treatment, IC increased 19\% (from 1.97 to $2.35 \mathrm{~L}$ ). The patient's FEV1 increased by only $9 \%$.

Flows from partial expiratory flow volume (PEFV) manoeuvres, such as the instantaneous flow at $30 \%$ of a control FVC manoeuvre ( $V^{\prime}$ p30), also reflect the response of COPD patients to bronchodilator therapy [30, 34]. PEFV curves are performed as a forced expiratory manoeuvre from end-tidal inspiratory with no pause at end inspiration [34]. The variable of interest is $V^{\prime}$ p30. Although PEFV manoeuvres can be performed with a spirometer, current spirometers will require additional software to make the measurements reproducible and easy to perform.

In comparison with flows from PEFV manoeuvres and IC, the responses to bronchodilator therapy are underestimated by FEV1 [34]. One-third of patients with chronic airflow obstruction treated with albuterol demonstrated a bronchodilator response based on FEV1. Two-thirds of the patients responded with changes in $V^{\prime}$ p30 or IC. Flow and volume history in VC manoeuvres can alter airway calibre and FEV1 contributes to the performance of these measurements [34, 35]. Of the two, IC appears to be the best available choice

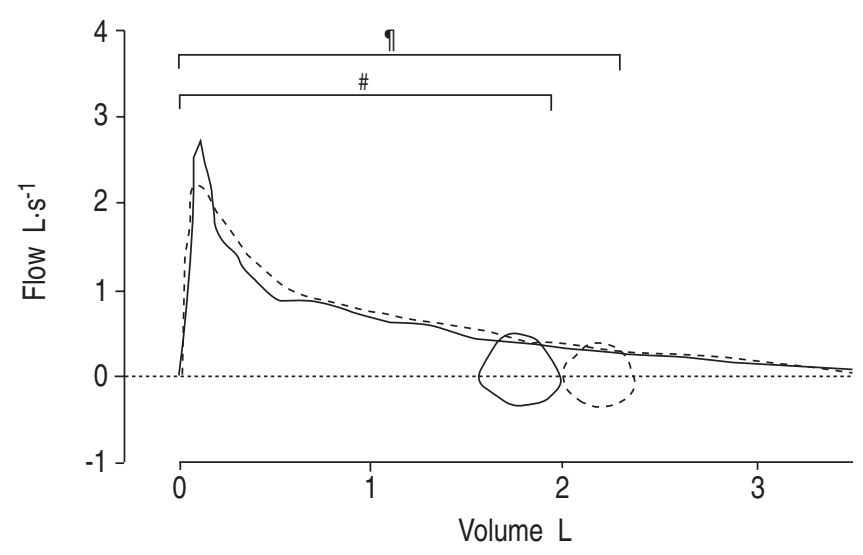

Fig. 2.-Flow/volume tracings for a male aged $40 \mathrm{yrs}$ with severe chronic obstructive pulmonary disease. Pre- (solid line) and post(dashed line) albuterol (bronchodilator) tracings show that inspiratory capacity (IC) increased 19\% (from 1.97 to $2.35 \mathrm{~L}$ ) after albuterol treatment. Illustrations for pre- (solid) and postalbuterol (dashed) tidal breaths are represented by the circular tracings on the figure. Forced expiratory volume in one second increased by only $9 \%$. \#: prealbuterol IC; $\uparrow$ : postalbuterol IC. 
because it can be measured easily with most laboratory spirometers.

Despite multiple studies showing the advantages of IC and PEFV parameters as outcome variables, these parameters have not yet found their way into routine clinical practice or COPD outcome studies. As may be expected by their infrequent use, IC and PEFV parameters involve some unresolved issues. Their measurement accuracy and precision are not well known and current pulmonary function testing guidelines do not yet address the details of their measurement. The absence of such standards will lead to increased variability in IC or $V^{\prime}$ p30 and could impact their clinical utility. Clinical practice is enhanced when clear methods of defining a response to therapy exist, but such criteria defining a response to therapy are not well established for these variables. The lung volume responses to bronchodilators have been found to be continuous so that responders could not be separated clearly from nonresponders [18]. An increase in IC of $10 \%$ pred IC $(\sim 0.3-0.4 \mathrm{~L})$, however, translated into clinically relevant improvements in dyspnoea and exercise performance [22].

Other physiological tests, such as timed-walk distance and the endurance shuttle-walk test also provide useful outcome information for treatments focused on symptoms and quality of life [36-38]. These simple tests do not require sophisticated equipment or training and involve an activity familiar even to severely impaired patients. Change in walk distance (rather than baseline measurements) correlates better with quality-oflife measures than do traditional spirometric measurements. A recent systematic review found the 6 -min walk test to be the most extensively researched and established functional walk test [38]. The timed- and shuttle-walking tests are increasing in importance as outcome measures in patients with respiratory diseases [37]. These tests also have the interesting feature of correlating better with quality-of-life measures than standard spirometric tests. The role of walk tests as outcome measures is increasing and evolving, but they are not a replacement for an assessment of health-related quality of life.

\section{Changes in pulmonary function over time}

Clinical decision-making for individual patients would be facilitated if it were known what change in pulmonary function was clinically relevant. For individual COPD patients, clinically relevant changes in spirometric parameters have not been defined in comparison with other measures of clinical improvement, including health-related quality of life. Statistically significant change is typically estimated in spirometry from measurements of within- and between-test variability. One such set of criteria from the ATS interpretative document [6] is illustrated in table 1. It should be emphasised that these criteria are an imperfect estimate of statistically significant change and not an estimate of a clinically important level

Table 1.-Significant changes in forced expiratory volume in one second $\left(F E V_{1}\right)$ over time as defined by the American Thoracic Society

Per cent change in FEV1 over time to be significant

Healthy subjects Patients with COPD

\begin{tabular}{lrl}
\hline Within-a-day & 5 & 13 \\
Week-to-week & 12 & 20 \\
Year-to-year & 15 & 15 \\
\hline
\end{tabular}

COPD: chronic obstructive pulmonary disease. Reproduced from [2] with permission. of improvement. Ascertaining clinically significant change in spirometric measures for COPD patients is an important issue that needs to be defined.

\section{Sputum induction}

The examination of sputum for inflammatory markers was considered to be difficult and unreliable, until 1992 when the technique of sputum induction made it possible to obtain sputum from the vast majority of healthy subjects [39, 40], as well as from subjects with airway diseases [41-43]. Methods of sputum analysis have been refined to provide reliable measurements for an increasing number of inflammatory biomarkers [44, 45]. Initially, these biomarkers were studied chiefly in patients with asthma [39, 40, 42], chronic cough [41], or smokers with chronic bronchitis without COPD [42]. Increasingly, they have been used in research to study the airway inflammation in COPD $[46,47]$ and in clinical practice to guide treatment.

Sputum induction is required when the sputum cannot be obtained spontaneously. Usually, it is performed with an aerosol of hypertonic saline in concentrations of 3,4 and $5 \%$, or just 3 or $4.5 \%$, four times for $5 \mathrm{~min}$ or three times for $7 \mathrm{~min}$ [48-51]; another method uses $4.5 \%$ for $30 \mathrm{~s}$ followed by 1,2 and 4 min [52]. This latter procedure takes up less time and thus may be the preferred method, if it is as safe and successful as the other methods. After each inhalation, the subject is asked to blow the nose, rinse the mouth with water, swallow (to minimise contamination with postnasal drip or saliva) and cough into a clear container.

The primary concern with sputum induction in patients with COPD or asthma is safety, since the aerosol of saline is a bronchoconstrictor stimulus [53]. The occurrence of bronchoconstriction can be reduced by using a relatively low output ultrasonic nebuliser, which does not reduce the success of induction $[54,55]$, and by the inhalation of a $\beta_{2}$-agonist (such as $200 \mu \mathrm{g}$ albuterol) to bronchodilate and prevent constriction [53-60]. Also, if there is a particular safety concern (such as when the patient has a low FEV1 or has been treated with a long-acting $\beta_{2}$-agonist or a short-acting $\beta_{2}$-agonist more than twice daily, i.e. when protection against bronchoconstriction may be reduced), normal saline can be used first for short periods (e.g. $30 \mathrm{~s}$ followed by 1, 2 and $4 \mathrm{~min}$ ) [61, 62]. The FEV1 is measured before and after each inhalation, and the inhalations are discontinued if there is a fall of $\geqslant 20 \%$. Any bronchoconstriction can be reversed by further inhalation of the bronchodilator.

Once it is understood how best to coax the subject to expectorate sputum and to recognise when this is accomplished, the procedure is successful in obtaining enough sputum for cell counts ( $>100 \mu \mathrm{g}$ of selected sputum) in $>90 \%$ of patients with COPD or asthma [59] and in $>80 \%$ of healthy subjects. Although the repeatability of success has not been specifically examined, adequate specimens for differential cell counts were obtained in $95 \%$ of 122 inductions in subjects with COPD [63] and in 100\% of subjects entered into trials of the effect of corticosteroid treatment [64-66]. The procedure can be time-consuming and take up to $1 \mathrm{~h}$ if three or more 5- or 7-min inhalations are required. However, the process can be shortened by terminating the procedure when enough sputum is obtained. In COPD, cell content does not change between the first and the last of three 7-min inhalations [67], although in asthma that is not severely uncontrolled, there are fewer eosinophils and neutrophils and lower concentrations of some fluid-phase measurements in the last sample [68-70]. 


\section{Sputum examination for markers of airway inflammation}

In processing and examining sputum, the colour of the sputum in the expectorate of sputum plus saliva is recorded as mucoid, mucopurulent or purulent [71, 72], or it can be graded according to a standard colour chart (BronkoTest; Heredilab Inc., Salt Lake City, UT, USA) [73].

The expectorate can be examined whole $[40,49,74]$ or it can be poured into a Petri dish and the sputum, which appears more opaque and dense, selected from the saliva [42, 44]. If the selection is performed optimally, contamination with salivary squamous cells is usually $<5 \%$ [75]. The specimen is weighed in an Eppendorf tube and a measured volume of freshly prepared $0.1 \%$ dithiothreitol is added and rocked for $15 \mathrm{~min}$ to break up the mucus and disperse the cells. The same volume of Dulbecco's phosphate-buffered saline is added and mixed, and the suspension is filtered through a $48-\mu \mathrm{m}$ nylon mesh. Cell viability with trypan blue and a total cell count is then determined in a haemocytometer and cytospins are prepared and stained for a 400-500 differential cell count. The cells can also be examined by immunocytochemistry [76-80], in situ hybridisation [81] or flow cytometry [82-84]. The filtrate can be spun to obtain the fluid phase, which is stored at $-70^{\circ} \mathrm{C}$ for future measurements $[44,45]$.

\section{Interpretation of sputum measurements}

The appearance of sputum is mucoid in healthy persons as well as many of those with asthma, chronic bronchitis or COPD. Mucopurulent or purulent sputum usually indicates a more intense neutrophilia [73], but it can be associated with an eosinophilia, especially in asthma [72] but also in COPD. Validation of the intensity of the neutrophilia and recognition of an eosinophilia requires cell counts. The former can also be indicated by fluid-phase neutrophil elastase levels [85].

Cell counts using induced sputum selected from the expectorate have been recorded in a healthy population of adults [86] (table 2) and children [87], whereas cell counts in the whole expectorate of sputum plus saliva have only been recorded in small numbers of subjects. The total cell count in selected sputum can be related to the weight of the sputum examined and so may be better compared between specimens or centres, than with the whole expectorate of sputum plus saliva in which the total count would also be expected to be lower. The differential cell counts in selected and whole samples are the same. The total cell count and proportion of neutrophils is variable between subjects; in contrast, the proportion of eosinophils is $<\sim 2 \%$. There is probably a grey area around this cut-off point of $2 \%$ between $1-3 \%$, and a level $>3 \%$ is usually regarded as definitely raised.

Cell counts in spontaneous and in selected induced sputum are the same $[88,89]$, as are those in the trachea and proximal bronchi [89]. However, induced sputum is of better quality in that it contains more viable cells. However, the distribution of

Table 2. - Selected sputum cell counts in healthy adults

\begin{tabular}{lrrrc}
\hline & Mean & 2 SD & Median & 90th Percentile \\
\hline Macrophages & 58.8 & 100.8 & 60.8 & 86.1 \\
Neutrophils & 37.5 & 77.7 & 36.7 & 64.4 \\
Bronchial epithelial cells & 1.6 & 9.4 & 0.3 & 4.4 \\
Lymphocytes & 1.0 & 3.2 & 0.5 & 2.6 \\
Eosinophils & 0.4 & 2.2 & 0.0 & 1.1 \\
Metachromatic cells & 0.0 & 0.1 & 0.0 & 0.04 \\
\hline
\end{tabular}

Adapted from data from [86].
Table 3. - Inflammatory markers in airway compartments

Sputum \% $\quad$ BW \% $\quad$ BAL \% $\quad$ Biopsy $\times 10^{6} \cdot \mathrm{mL}^{-1}$

\begin{tabular}{lcccc}
\hline Neutrophils & 77.3 & 5.5 & 1.7 & 385 \\
Macrophages & 19.4 & 55.3 & 85.8 & 1155 \\
Lymphocytes & 1.9 & 3.5 & 6.9 & 935 \\
Eosinophils & 1.2 & 0.5 & 0.4 & 30 \\
IL- $8 \mu \mathrm{g} \cdot \mathrm{L}^{-1}$ & 13400 & 160 & 40 & \\
$\mathrm{ECP} \mu \mathrm{g} \cdot \mathrm{L}^{-1}$ & 750 & 4 & 16 & \\
\hline
\end{tabular}

Data are presented as median values; BW: bronchial wash; BAL: bronchoalveolar lavage; IL: interleukin; ECP: eosinophil cationic protein. Reproduced from [94] with permission.

cells in different compartments of the airway and the airway wall in health or disease differ from one another [90-94]. Thus, neutrophils and eosinophils predominate in sputum, macrophages and lymphocytes predominate in bronchoalveolar lavage, and lymphocytes predominate in bronchial biopsies [94] (table 3).

Good measurements should demonstrate reliability (reproducibility), validity and responsiveness to change. The major cell types in sputum from people with airway diseases (macrophages, neutrophils and eosinophils) fulfill these criteria [42]. The reliability of the total cell count, metachromatic cells and lymphocytes is less. Metachromatic cells and lymphocytes are present in small numbers. Metachromatic cells need to be fixed in Carnoy's, stained with toluidine blue and a count of 1,500 cells performed for accuracy. Lymphocytes are difficult to recognise accurately, but accuracy can be improved by immunocytochemistry [95].

Normal values for fluid-phase markers of airway inflammation have not been documented in healthy populations. They are variable between studies depending upon the examination of selected sputum or the whole expectorate and the choice of method to measure them (bioassay, enzyme assay or immunoassay) [44, 45]. Immunoassays are the method of choice because of their convenience, reproducibility and specificity. Although several measurements are reliable and responsive to change, the content validity of most has not been studied and this can be affected by the treatment with dithiothreitol [44, 45, 96-98].

\section{Sputum inflammatory markers in chronic obstructive pulmonary disease}

The characteristic sputum changes in smokers or nonsmokers with COPD are neutrophilia [43, 62, 94, 99-101], increased neutrophil proteases (myeloperoxidase (MPO) [43, 73, 98, 102-104], elastase [73, 98, 102-104] and human neutrophil lipokalin [43]), increased chemokines (interleukin (IL)-8 [73, 98, 102-106], IL-6 [98, 107], tissue necrosis factor (TNF)- $\alpha[98,106]$ and leukotriene (LT)B 4 [98, 103, 104, 108]) and increased markers of remodelling (matrix metalloproteinase-1 [109] and -9 [110], and a decrease in secretory leukocyte protease inhibitor (SLPI) [98, 104, 109] and tissue inhibitor of metalloproteinase-1 $(109,110])$. Sputum processed with ditheothreitol significantly reduces the detectable concentration of TNF- $\alpha, \mathrm{LTB}_{4}$ and MPO; IL-1 $\beta$, IL-6, IL-8, SLPI and neutrophil elastase are unaffected [98].

The neutrophil is a highly labile cell as indicated by the variability seen between healthy persons [86] and by the number of stimuli that cause it to increase [111]. It is increased a number of hours after sputum induction and by cigarette smoke, air pollutants, endotoxin, some occupational exposures and viral or bacterial infections. Therefore, a neutrophilia is not specific for COPD. It can be found in some 
smokers without COPD and in some nonsmokers with asthma [42]. However, in cigarette smokers with COPD, the degree of neutrophilia relates loosely to the degree of chronic airflow limitation [106] and the degree of progressive airflow limitation [99]. This, as well as the observation that leukocytespecific integrin CD11b/CD18 expressed on neutrophils [76] can be related to the severity of COPD, raises the possibility that sputum neutrophils or one or more of the markers related to them, may be used as early indicators for the development of COPD. This requires careful investigation.

There is now a renewed interest in studying the effect of drugs on the neutrophilic inflammation in COPD. One study has reported that sputum neutrophils are reduced after 2 months of treatment with $1,500 \mu \mathrm{g}$ daily inhaled beclomethasone [112]. This requires further study, since it is contrary to the known effect of corticosteroids to prolong the life of neutrophils and the general lack of influence of long-term inhaled steroid treatment on progression of the disease. In another study, theophylline reduced induced sputum neutrophils, IL-8, MPO and lactoferrin [113].

Some patients with chronic bronchitis or COPD have an increase in the proportion of eosinophils in sputum [114, 115] (table 4), as is characteristically seen in uncontrolled asthma [42, 61] and in nonsmokers with eosinophilic bronchitis without asthma [116, 117]. Eosinophils have also been reported to increase in some exacerbations of COPD [118], since they increase in many asthma exacerbations [61]. The prevalence of sputum eosinophilia in COPD has not been examined in a population study. However, sputum eosinophilia is important because it appears to be associated with clinical improvement (postbronchodilator FEV1, quality of life) after treatment with prednisone or prednisolone (fig. 3). The greater the eosinophilia, the greater the improvement achieved with the steroid [64-66] (fig. 4). The effect of (shortand long-term) inhaled corticosteroids needs to be examined further in COPD because in patients with asthma [119] or with chronic cough with sputum eosinophilia but without asthma [41, 120, 121], inhaled corticosteroids produce clinical improvement. Therefore, the examination of sputum for eosinophilia may be useful in clinical practice to identify those patients who would benefit from steroid treatment.

Patients with COPD also have an increase in eosinophil proteins, such as eosinophil cationic protein (ECP) [43, 64, 94, 114, 122-124], eosinophil peroxidase (EPO) [43, 122, 123] and mast cell tryphase [125]. ECP is found in both eosinophils and neutrophils, whereas EPO is said to be a unique component of eosinophils [126]. However, the value of the measurements in COPD is not well understood, especially when their increased levels are not related to an increase in eosinophils and not associated with successful use of prednisolone [64, 123]. That ECP correlates with neutrophils in healthy persons [127]
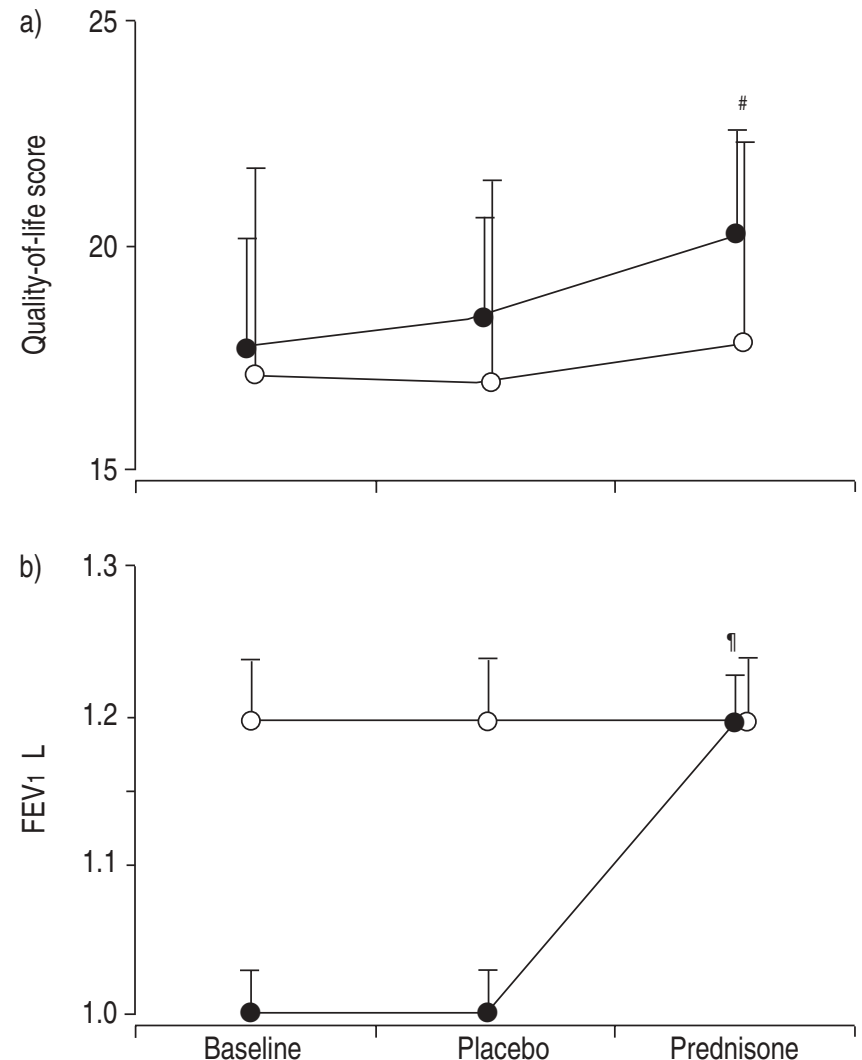

Fig. 3. - Effect of prednisone on a) quality of life and b) postbronchodilator forced expiratory volume in one second (FEV 1 ) in smokers with severe airflow limitation with sputum eosinophilia. Compared with placebo, the mean-paired difference produced by prednisone in patients with eosinophilia $(\geqslant 3 \% ;-0)$ was 1.96 points $(95 \%$ confidence interval $0.3-3.3$ points; $\mathrm{p}=0.01)$ for quality of life and $0.11 \mathrm{~L}(-0.09$ $0.22 \mathrm{~L} ; \mathrm{p}=0.05$ ) for postbronchodilator $\mathrm{FEV}$. In patients without sputum eosinophilia $(\bigcirc)$, prednisone produced no improvement in either quality-of-life score ( 0.9 points, $-0.4-2.2$ points) or postbronchodilator FEV1 $(0.01 \mathrm{~L},-0.04-0.09 \mathrm{~L}){ }^{\#}: \mathrm{p} \leqslant 0.01 ;{ }^{\uparrow}: \mathrm{p}=0.05$. Reproduced from [64] with permission.

raises the possibility that it may be a product of neutrophils or taken up by them [126].

Although some exacerbations of COPD are associated with sputum eosinophilia, they are associated more usually with neutrophilia. Exacerbations of COPD, therefore, could be classified into eosinophilic, neutrophilic, neutrophilic plus eosinophilic and noneosinophilic plus non-neutrophilic. The incidence of these different types of exacerbation should be examined and correlated with purulence, bacterial cultures and virus reverse transcriptase-polymerase chain reaction.

Table 4.-Selected induced sputum: markers of inflammation

\begin{tabular}{|c|c|c|c|c|c|}
\hline & \multirow[t]{2}{*}{ Healthy } & \multirow[t]{2}{*}{ Stable asthma } & \multicolumn{3}{|c|}{ Smokers' bronchitis } \\
\hline & & & No COPD & COPD-Eo & COPD+Eo \\
\hline TCC $\times 10^{6} \cdot \mathrm{g}^{-1}$ & 3.1 & 3.3 & 3.9 & 11.1 & 8.3 \\
\hline Eosinophils \% & 0.5 & 5.2 & 0.3 & 1 & 5.4 \\
\hline Neutrophils \% & 24.5 & 46.9 & 33 & 83.4 & 73.4 \\
\hline $\mathrm{ECP} \mu \mathrm{g} \cdot \mathrm{L}^{-1}$ & 288 & 1040 & 352 & 2560 & 5240 \\
\hline Elastase $\mu \mathrm{g} \cdot \mathrm{L}^{-1}$ & 297 & 534 & 241 & 2512 & 2996 \\
\hline Fibrinogen $\mu \mathrm{g} \cdot \mathrm{L}^{-1}$ & 440 & 2080 & 708 & 18100 & 24600 \\
\hline IL-5 $\mathrm{pg} \cdot \mathrm{mL}^{-1}$ & UL & 46.3 & UL & UL & UL \\
\hline
\end{tabular}

Data are presented as median values. COPD: chronic obstructive pulmonary disease; Eo: eosinophilia ( $>3 \%)$ in sputum; TCC: total cell count. ECP: eosinophil cationic protein; IL: interleukin; UL: under limit of detection. Reproduced from [114] with permission. 

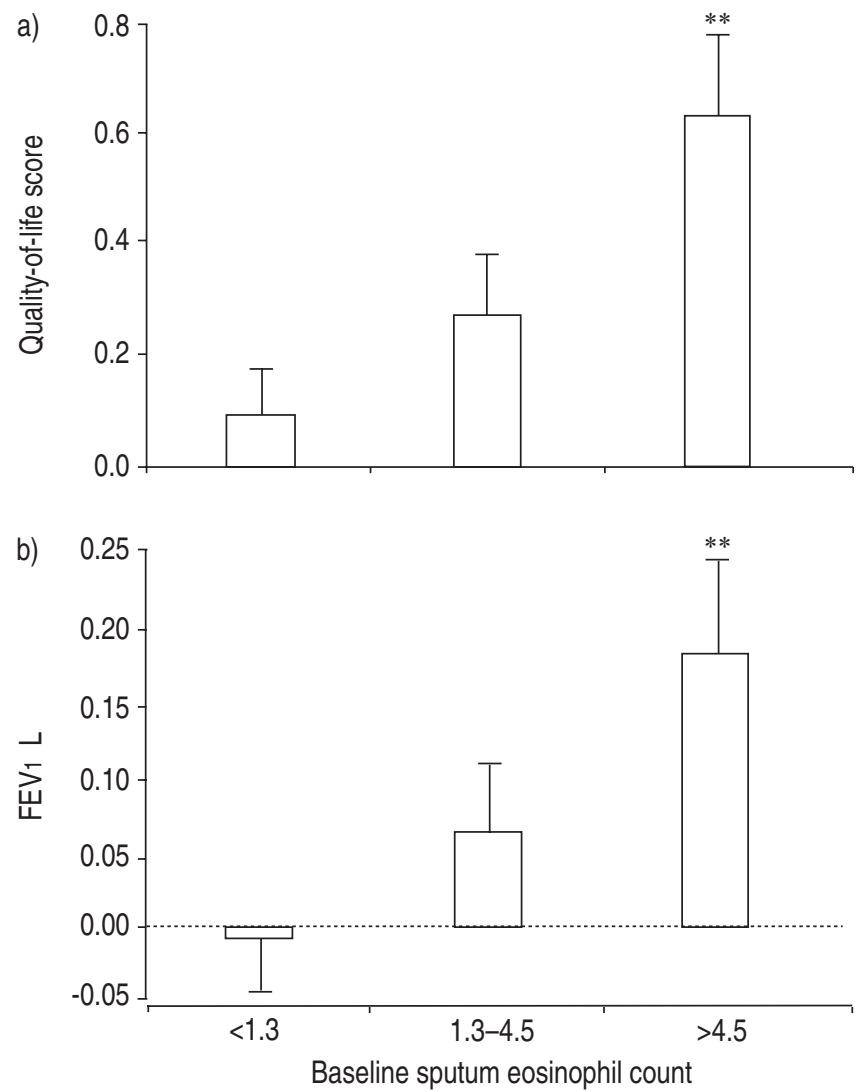

Fig. 4.-Increase in a) quality-of-life score and b) forced expiratory volume in one second $\left(F E V_{1}\right)$ after prednisolone. Sixty-seven patients were divided into tertiles according to their baseline eosinophil count $(<1.3 \%, 1.3-4.5 \%,>4.5 \%)$. Treatment with prednisolone progressively improved the mean \pm SEM postbronchodilator FEV 1 and mean \pm SEM total quality-of-life scores (Chronic Respiratory Questionnaire) from the lowest to the highest tertile of eosinophilia compared with placebo. **: $\mathrm{p}<0.01$. Reproduced from [65] with permission.

Neutrophilic exacerbations need to be expressed with both total and differential cell counts. In asthmatic subjects with viral infections caused by influenza or respiratory syncytial virus, the total cell counts were reported at $\sim 20$ million $\cdot \mathrm{mL}^{-1}$ and the differential neutrophils at $\sim 60 \%[128,129]$; the specimens were mucoid. In bacterial infections in persons with asthma, the total cell counts can be much higher (up to 100 million $\cdot \mathrm{mL}^{-1}$ or so of selected sputum) and the differential neutrophils are usually $\geqslant 80 \%$ [72]. In COPD, sputum cell counts during exacerbations or colonisation have generally not been reported. However, in exacerbations due to rhinovirus in COPD, the total and differential counts did not change significantly between baseline and the exacerbation, but the values were not given [108]. There was also an increase in IL-6. In bacterial infections due to Haemophilus influenzae or Moraxella catarrhalis there was an increase in neutrophil elastase activity and $\mathrm{LTB}_{4}$, which fell with recovery, and the sputum was mucopurulant or purulant [85]. Smaller changes were observed with $H$. parainfluenzae and in mucoid exacerbations. In these, the sputum is usually mucopurulent or purulent depending on the intensity of the neutrophilia. Further studies of the effects of infections on cell counts in COPD and the response to treatment are needed.

Finally, the macrophages in smokers' sputum contain smokers' inclusions [130, 131], an indicator of exposure that can persist for years after smoking has been discontinued. It seems unlikely that the degree of smokers' inclusions is greater in smokers with COPD compared with those without COPD, although this should be examined specifically.

\section{Conclusions}

Chronic obstructive pulmonary disease is defined as obstructive lung disease that does not respond to bronchodilators using the basic spirometric parameters of forced expiratory volume in one second/forced vital capacity ratio and reduced forced expiratory volume in one second. Since these parameters have not been as useful in evaluating the response to various therapies, spirometric values other than forced expiratory volume in one second (peak flow, mid-flows, inspiratory capacity and partial expiratory flow volume variables) have been proposed as potentially valuable physiological measures for chronic obstructive pulmonary disease. None of these have reached practical acceptance, but inspiratory capacity and instantaneous flow at $30 \%$ of a control forced vital capacity manoeuvre appear to be the most promising spirometric values. Functional tests, including 6-min and shuttlewalk tests have demonstrated a closer correlation to outcome variables, including symptom severity and quality of life. At present, it may be useful in predicting a patient's responses to corticosteroid treatment. The analysis of induced sputum in the chronic obstructive pulmonary disease patient will enable a better understanding of the pathophysiology of chronic obstructive pulmonary disease and its treatment.

\section{References}

1. Pauwels RA, Buist AS, Ma P, Jenkins CR, Hurd SS. Global strategy for the diagnosis, management, and prevention of chronic obstructive pulmonary disease: NHLBI/WHO Global Initiative for Chronic Obstructive Lung Disease (GOLD) Workshop Summary. Am J Respir Crit Care Med 2001; 163: 1256-1276.

2. American Thoracic Society. Statement. Standards for the diagnosis and care of patients with COPD. Am J Respir Crit Care Med 1995; 152: S77-S120.

3. Siafakas NM, Vermeire P, Pride NB, et al. Optimal assessment and management of chronic obstructive pulmonary disease (COPD). The European Respiratory Society Task Force. Eur Respir J 1995; 8: 1398-1420.

4. British Thoracic Society. Guidelines for the management of chronic obstructive pulmonary disease. The COPD Guidelines Group of the Standards of Care Committee of the BTS. Thorax 1997; 52: Suppl. 5, S1-S28.

5. Laitinen LA, Koskela K. Chronic bronchitis and chronic obstructive pulmonary disease: Finnish National Guidelines for Prevention and Treatment 1998-2007. Respir Med 1999; 93: $297-332$.

6. American Thoracic Society. Statement. Lung function testing: selection of reference values and interpretive strategies. Am Rev Respir Dis 1991; 144: 1202-1218.

7. Hankinson JL, Bang KM. Acceptability and reproducibility criteria of the American Thoracic Society as observed in a sample of the general population. Am Rev Respir Dis 1991; 143: 516-521.

8. Enright PL, Johnson LR, Connett JE, Voelker H, Buist AS. Spirometry in the Lung Health Study. 1. Methods and quality control. Am Rev Respir Dis 1991; 143: 1215-1223.

9. Stoller JK, Buist AS, Burrows B, et al. Quality control of spirometry testing in the registry for patients with severe alpha 1-antitrypsin deficiency. Alpha-Antitrypsin Deficiency Registry Study Group. Chest 1997; 111: 899-909.

10. Eaton T, Withy S, Garrett JE, Mercer J, Whitlock RM, Rea HH. Spirometry in primary care practice: the importance of quality assurance and the impact of spirometry workshops. Chest 1999; 116: 416-423.

11. Waterer GW, Wan JY, Kritchevsky SB, et al. Airflow limitation is underrecognized in well-functioning older people. J Am Geriatr Soc 2001; 49: 1032-1038.

12. Hankinson JL, Odencrantz JR, Fedan KB. Spirometric 
reference values from a sample of the general US population. Am J Respir Crit Care Med 1999; 159: 179-187.

13. American Thoracic Society. Statement. Standardization of spirometry: 1994 update. Am J Respir Crit Care Med 1995; 152: 1107-1136.

14. Swanney MP, Jensen RL, Crichton DA, Beckert LE, Cardno LA, Crapo RO. FEV6 is an acceptable surrogate for FVC in the spirometric diagnosis of airway obstruction and restriction. Am J Respir Crit Care Med 2000; 162: 917919.

15. Jensen RL, Crapo RO. FEV6 can be estimated when expiratory times are as short as three seconds. Am J Respir Crit Care Med 2000; 161: A275.

16. Thiadens HA, De Bock GH, van Houwelingen JC, et al. Can peak expiratory flow measurements reliably identify the presence of airway obstruction and bronchodilator response as assessed by FEV1 in primary care patients presenting with a persistent cough? Thorax 1999; 554: 1055-1060.

17. Pride NB. Forced oscillation techniques for measuring mechanical properties of the respiratory system. Thorax 1992; 47: 317-320.

18. Hadcroft J, Calverley PM. Alternative methods for assessing bronchodilator reversibility in chronic obstructive lung disease. Thorax 2001; 56: 713-720.

19. The Lung Health Study Research Group. Effect of inhaled triamcinolone on the decline in pulmonary function in chronic obstructive pulmonary disease. $N$ Engl J Med 2000; 343: 1902-1909.

20. Yusen RD. What outcomes should be measured in patients with COPD? Chest 2001; 119: 327-328.

21. Harper R, Brazier JE, Waterhouse JC, Walters SJ, Jones NB, Howard P. Comparison of outcome measures for patients with chronic obstructive pulmonary disease (COPD) in an outpatient setting. Thorax 1997; 52: 879-887.

22. O'Donnell DE, Forkert L, Webb KA. Evaluation of bronchodilator responses in patients with "irreversible emphysema". Eur Respir J 2001; 18: 914-920.

23. Milic-Emili J. Inspiratory capacity and exercise tolerance in chronic obstructive pulmonary disease. Can Respir J 2000; 7 : 282-285.

24. Cerveri I, Pellegrino R, Dore R, et al. Mechanisms for isolated volume response to a bronchodilator in patients with COPD. J Appl Physiol 2000; 88: 1989-1995.

25. O'Donnell DE, Lam M, Webb KA. Measurement of symptoms, lung hyperinflation, and endurance during exercise in chronic obstructive pumonary disease. $A m J$ Respir Crit Care Med 1998; 158: 1557-1565.

26. O'Donnell DE, Webb KA. Breathlessness in patients with severe chronic airflow limitation. Physiologic correlations. Chest 1992; 102: 824-831.

27. Marin JM, Carrizo SJ, Gascon M, Sanchez A, Gallego B, Cellil BR. Inspiratory capacity, dynamic hyperinflation, breathlessness, and exercise performance during the 6-minute walk test in chronic obstructive pulmonary disease. $\mathrm{Am} \mathrm{J}$ Respir Crit Care Med 2001; 163: 1395-1399.

28. Diaz O. Role of inspiratory capacity on exercise tolerance in COPD patients with and without tidal expiratory flow limitation at rest. Eur Respir J 2000; 16: 260-275.

29. O'Donnell DE, Lam M, Webb KA. Spiromentric correlates of improvement in exercise performance after anticholinergic therapy in chronic obstructive pulmonary disease. $\mathrm{Am} J$ Respir Crit Care Med 1999; 160: 542-549.

30. Pellegrino R, Rodarte JR, Brusasco V. Assessing the reversibility of airway obstruction. Chest 1998; 114: 1607-1612.

31. Belman MJ, Botnick WC, Shin JW. Inhaled bronchodilators reduce dynamic hyperinflation during exercise in patients with chronic obstructive pulmonary disease. Am J Respir Crit Care Med 1996; 153: 967-975.

32. Yan S, Kaminski D, Sliwinski P. Reliability of inspiratory capacity for estimating end-expiratory lung volume changes during exercise in patients with chronic obstructive pulmonary disease. Am J Respir Crit Care Med 1997; 156: 55-59.
33. Murariu C, Ghezzo H, Milic-Emili J, Gautier H. Exercise limitation in obstructive lung disease. Chest 1998; 114: 965968.

34. Pellegrino R, Brusasco V. Lung hyperinflation and flow limitation in chronic airway obstruction. Eur Respir J 1997; 10: $543-549$.

35. Brusasco V. Vital capacities in acute and chronic airway obstruction: dependence on flow and volume. Eur Respir $J$ 1997; 10: 1316-1320.

36. Revill SM, Morgan MD, Singh SJ, Williams J, Hardman AE. The endurance shuttle walk: a new field test for the assessment of endurance capacity in chronic obstructive pulmonary disease. Thorax 1999; 54: 213-222.

37. Sciurba FC, Slivka WA. Six-minute walk testing. Semin Respir Crit Care Med 1998; 19: 383-392.

38. Solway S, Brook D, Lacasse Y, Thomas S. A qualitative systematic overview of the measurement properties of functional walk tests used in the cardiorespiratory domain. Chest 2001; 119: 256-270.

39. Pin I, Gibson PG, Kolendowicz R, et al. Use of induced sputum cell counts to investigate airway inflammation in asthma. Thorax 1992; 47: 25-29.

40. Fahy JV, Liu J, Wong $\mathrm{H}$, et al. Cellular and biochemical analysis of induced sputum from asthmatic and from healthy subjects. Am Rev Respir Dis 1993; 147: 1126-1131.

41. Gibson PG, Dolovich J, Denburg JA, Ramsdale EA, Hargreave FE. Chronic cough: eosinophilic bronchitis without asthma. Lancet 1989; 1: 1346-1348.

42. Pizzichini E, Pizzichini MM, Efthimiadis A, et al. Indices of airway inflammation in induced sputum: reproducibility and validity of cell and fluid-phase measurements. Am J Respir Crit Care Med 1996; 154: 308-317.

43. Keatings VM, Barnes PJ. Granulocyte activation markers in induced sputum: comparison between chronic obstructive pulmonary disease, asthma and normal subjects. Am J Respir Crit Care Med 1997; 155: 449-453.

44. Kelly MM, Efthimiadis A, Hargreave FE. Induced sputum: selection method. In: Rogers DF, Donnelly LE, eds. Methods in Molecular Medicine. Human Airway Inflammation: Sampling Techniques and Analytical Protocols. London, Humana Press, 2001; pp. 77-92.

45. Kelly MM, Keatings V, Leigh R, et al. Analysis of fluidphase mediators. Eur Respir J 2002; 20: Suppl. 37, 24s-39s.

46. Rutgers SR, Tioens W, Kauffman HF, Postma DS. Markers of active airway inflammation and remodelling in chronic obstructive pulmonary disease. Clin Exp Allergy 2001; 31: 193-205.

47. Weilders PL, Dekhuijzen PN. Disease monitoring in chronic obstructive pulmonary disease: is there a role for biomarkers? Eur Respir J 1997; 10: 2443-2445.

48. in't Veen JC, de Gouw HW, Smits HH, et al. Repeatability of cellular and soluble markers of inflammation in induced sputum from patients with asthma. Eur Respir J 1996; 9: 2441-2447.

49. Gershman NH, Wong HH, Liu JT, Mahlmeister MJ, Fahy JV. Comparison of two methods of collecting induced sputum in asthmatic subjects. Eur Respir J 1996; 9: 2448-2453.

50. Pavord ID, Pizzichini MM, Pizzichini E, Hargreave FE. The use of induced sputum to investigate airway inflammation. Thorax 1997; 52: 498-501.

51. Paggiaro L, Chanez P, Holz O, et al. Sputum induction. Eur Respir J 2002; 20: Suppl. 37, 3s-8s.

52. Gibson PG, Wlodarczyk JW, Hensley MJ, et al. Epidemiological association of airway inflammation with asthma symptoms and airway hyperresponsiveness in childhood. $\mathrm{Am}$ J Respir Crit Care Med 1998; 158: 36-41.

53. Pizzichini E, Pizzichini MMM, Leigh R, Djukanovic R, Sterk PJ. Safety of sputum induction. Eur Respir $J$ 2002; 20: Suppl. 37, 9s-18s.

54. Popov TA, Pizzichini MMM, Pizzichini E, et al. Some technical factors influencing the induction of sputum for cell analysis. Eur Respir J 1995; 8: 559-565. 
55. Kelly MG, Martin SL, Ennis M, Elborn JS. Comparison of sputum induction using high-output and low-output ultrasonic nebulizers in normal subjects and patients with COPD. Chest 2002; 122: 955-959.

56. Wong HH, Fahy JV. Safety of one method of sputum induction in asthmatic subjects. Am J Respir Crit Care Med 1997; 156: 299-303.

57. de la Fuente PT, Romagnoli M, Godard P, Bousquet J, Chanez P. Safety of inducing sputum in patients with asthma of varying severity. Am J Respir Crit Care Med 1998; 157: $1127-1130$.

58. Hunter CJ, Ward R, Woltmann G, Wardlaw HJ, Pavord ID. The safety and success rate of sputum induction using a low output ultrasonic nebuliser. Respir Med 1999; 93: 345-348.

59. Vlachos-Mayer H, Leigh $\mathrm{R}$, Sharon RF, Hussak $\mathrm{P}$, Hargreave FE. Success and safety of sputum induction in the clinical setting. Eur Respir J 2000; 16: 997-1000.

60. Rytila PH, Lindqvist AE, Laitinen LA. Safety of sputum induction in chronic obstructive pulmonary disease. Eur Respir J 2000; 15: 1116-1119.

61. Pizzichini MM, Pizzichini E, Clelland L, et al. Sputum in severe exacerbations of asthma: kinetics of inflammatory indices after prednisone treatment. Am J Respir Crit Care Med 1997; 155: 1501-1508.

62. Wark PA, Siopson JL, Hensley MJ, Gibson PG. Safety of sputum induction with isotonic saline in adults with acute severe asthma. Clin Exp Allergy 2001; 31: 1745-1753.

63. Brightling W, Monterio $\mathrm{RH}$, Green $\mathrm{RH}$, et al. Induced sputum and other outcome measures in chronic obstructive pulmonary disease: safety and repeatability. Respir Med 2001; 95: 999-1002.

64. Pizzichini E, Pizzichini MM, Gibson PG, et al. Sputum eosinophilia predicts benefit from prednisone in smokers with chronic obstructive bronchitis. Am J Respir Crit Care Med 1998; 158: 1511-1517.

65. Brightling $\mathrm{CD}$, Monteiro W, Ward R, et al. Sputum eosinophilia and short-term response to prednisolone in chronic obstructive pulmonary disease: a randomised controlled trial. Lancet 2000; 357: 1480-1485.

66. Fujimoto K, Kubo K, Yamamoto H, Yagamuchi S, Matsuzawa Y. Eosinophilic inflammation in the airway is related to glucocorticoid reversibility in patients with pulmonary emphysema. Chest 1999; 115: 697-702.

67. Bhowmik A, Seemungal TA, Sapsford RJ, Devalia JL, Wedzicha JA. Comparison of spontaneous and induced sputum for investigation of airway inflammation in chronic obstructive pulmonary disease. Thorax 1998; 53: 953-956.

68. Holz O, Jorres RA, Koschyk S, et al. Changes in sputum composition during sputum induction in healthy and asthmatic subjects. Clin Exp Allergy 1998; 28: 284-292.

69. Belda J, Hussack P, Dolovich M, et al. Sputum induction: effect of nebulizer output and inhalation time on cell counts and fluid-phase measures. Clin Exp Allergy 2001; 31: 17401744.

70. Gershman NH, Liu H, Wong HH, et al. Fractional analysis of sequential induced sputum samples during sputum induction: evidence that different lung compartments are sampled at different time points. J Allergy Clin Immunol 1999; 104: 322-328.

71. Stockley RA, Hill SL, Morrison HM, et al. Elastolytic activity of sputum and its relation to purulence and to lung function in patients with bronchiectasis. Thorax 1984; 39: 408-413.

72. Berlyne GS, Efthimiadis A, Hussack P, et al. Sputum in asthma: colour versus cell counts. J Allergy Clin Immunol 2000; 105: 182-183.

73. Stockley RA, Bayley DL, Hill SL, et al. Assessment of airway neutrophils by sputum colour: correlation with airways inflammation. Thorax 2001; 56: 366-372.

74. Keatings VM, Nightingale JA. Induced sputum. Whole sample. In: Rogers DF, Donnelly LE, eds. Methods in Molecular Medicine: Human Airway Inflammation: Sampling
Techniques and Analytical Protocols. London, Humana Press, 2001; pp. 93-98.

75. Pizzichini E, Pizzichini MM, Efthimiadis A, Hargreave FE, Dolovich J. Measurement of inflammatory indices in induced sputum: effects of selection of sputum to minimize salivary contamination. Eur Respir J 1996; 9: 1174-1180.

76. Maestrelli $\mathrm{P}$, Calcagni $\mathrm{PG}$, Saetta $\mathrm{M}$, et al. Integrin upregulation on sputum neutrophils in smokers with chronic airway obstruction. Am J Respir Crit Care Med 1996; 154: 1296-1300.

77. Lensmar C, Elmberger G, Sandgren P, Skold CM, Eklund A. Leukocyte counts and macrophage phenotypes in induced sputum and bronchoalveolar lavage fluid from normal subjects. Eur Respir $J$ 1998; 12: 595-600.

78. in't Veen JC, Grootendorst DC, Bel EH, et al. CD11b and L-selectin expression on eosinophils and neutrophils in blood and induced sputum of patients with asthma compared with normal subjects. Clin Exp Allergy 1998; 29: 606-615.

79. Gauvreau GM, Watson RM, O'Byrne PM. Kinetics of allergen-induced airway eosinophilic cytokine production and airway inflammation. Am J Respir Crit Care Med 1996; 160: 640-647.

80. Gelder CM, Thomas PS, Yates DH, Adcock IM, Morrison JJ, Barnes PJ. Cytokine expression in normal, atopic, and asthmatic subjects using the combination of sputum induction and the polymerase chain reaction. Thorax 1995; 50: 1033-1037.

81. Olivenstein R, Thaha R, Minshall EM, Hamid AQ. IL-4 and IL-5 mRNA expression in induced sputum of asthmatic subjects: comparison with bronchial wash. J Allergy Clin Immunol 1999; 103: 238-245.

82. Hansel TT, Braunstein JB, Walker C, et al. Sputum eosinophils from asthmatics express ICAM-1 and HLADR. Clin Exp Immunol 1991; 86: 271-277.

83. Kidney JC, Wong AG, Efthimiadis A, et al. Elevated B cells in sputum of asthmatics: close correlation with eosinophils. Am J Respir Crit Care Med 1996; 153: 540-544.

84. Louis R, Shute J, Biagi S, et al. Cell infiltration, ICAM-1 expression, and eosinophil chemotactic activity in asthmatic sputum. Am J Respir Crit Care Med 1997; 155: 466-472.

85. Gompertz S, O'Brien C, Bayley DL, Hill SL, Stockley RA. Changes in bronchial inflammation during acute exacerbations of chronic bronchitis. Eur Respir J 2001; 17: 1112-1119.

86. Belda J, Keigh R, Parameswaran K, O'Byrne PM, Sears MR, Hargreave FE. Induced sputum cell counts in healthy adults. Am J Respir Crit Care Med 2000; 161: 475-478.

87. Cai Y, Carty K, Henry RL, Gibson PG. Persistence of sputum eosinophilia in children with controlled asthma when compared with healthy children. Eur Respir J 1998; 11: 848-853.

88. Pizzichini MM, Popov TA, Efthimiadis A, et al. Spontaneous and induced sputum to measure indices of airway inflammation in asthma. Am J Respir Crit Care Med 1996; 154: 866-869.

89. Moodley YP, Krishnan V, Lalloo UG. Neutrophils in induced sputum arise from central airways. Eur Respir $J$ 2000; 15: 36-40.

90. Fahy JV, Wong H, Liu J, Boushey HA. Comparison of samples collected by sputum induction and bronchoscopy from asthmatic and healthy subjects. Am J Respir Crit Care Med 1995; 152: 53-58.

91. Maestrelli P, Saetta M, Di Stefano A, et al. Comparison of leukocyte counts in sputum, bronchial biopsies and bronchoalveolar lavage. Am J Respir Crit Care Med 1995; 152: 19261931.

92. Grootendorst DC, Sont JK, Willems LN, et al. Comparison of inflammatory cell counts in asthma: induced sputum vs bronchoalveolar lavage and bronchial biopsies. Clin Exp Allergy 1997; 27: 769-779.

93. Keatings VM, Evans DJ, O'Connor BJ, Barnes PJ. Cellular profiles in asthmatic airways: a comparison of induced sputum, bronchial washings, and bronchoalveolar lavage fluid. Thorax 1997; 52: 372-374. 
94. Rutgers SR, Tioens W, Kaufmann HF, van der Mark TW, Koeter GH, Postma DS. Comparison of induced sputum with bronchial wash, bronchoalveolar lavage and bronchial biopsies in COPD. Eur Respir J 2000; 15: 109-115.

95. Lemiere C, Taha R, Olivenstein R, Hamid Q. Comparison of cellular composition of induced sputum analyzed by Wright staining and immunocytochemistry. J Allergy Clin Immunol 2001; 108: 521-523.

96. Kelly MM, Leigh R, Carruthers S, et al. Increased detection of interleukin-5 in sputum by addition of protease inhibitors. Eur Respir J 2001; 18: 685-691.

97. Stockley RA, Bayley DL. Validation of assays for inflammatory mediators in sputum. Eur Respir J 2000; 15: 779-781.

98. Woolhouse IS, Bayley DL, Stockley RA. Effect of sputum processing with dithiothreitol on the detection of inflammatory mediators in chronic bronchitis and bronchiectasis. Thorax 2002; 57: 667-671.

99. Stanescu D, Sanna A, Veriter C, et al. Airways obstruction, chronic expectoration, and rapid decline of FEV1 in smokers are associated with increased levels of sputum neutrophils. Thorax 1996; 51: 267-271.

100. Ronchi MC, Piragino C, Rosi E, Amendola M, Duranti R, Scano G. Role of sputum differential cell count in detecting airway inflammation in patients with chronic bronchial asthma or COPD. Thorax 1996; 51: 1000-1004.

101. Peleman RA, Rytila PH, Kips JC, Joos GF, Pauwels RA. The cellular composition of induced sputum in chronic obstructive pulmonary disease. Eur Respir J 1999; 13: 839-843.

102. Hill AT, Bayley DL, Stockley RA. The interrelationship of sputum inflammatory markers in patients with chronic bronchitis. Am J Respir Crit Care Med 1999; 160: 893-898.

103. Crooks SW, Bayley DL, Hill SL, Stockley RA. Bronchial inflammation in acute bacterial exacerbations of chronic bronchitis: the role of leukotriene B4. Eur Respir J 2000; 15 : 274-280.

104. Hill AT, Bayley DL, Campbell EJ, Hill SL, Stockley RA. Airways inflammation in chronic bronchitis: the effects of smoking and alpha1-antitrypsin deficiency. Eur Respir $J$ 2000; 15: 886-890.

105. Yamamoto C, Yoneda T, Yoshikawa M, et al. Airway inflammation in COPD assessed by sputum levels of interleukin-8. Chest 1997; 112: 505-510.

106. Keatings VM, Collins PD, Scott DM, Barnes PJ. Differences in interleukin-8 and tumor necrosis factor-alpha in induced sputum from patients with chronic obstructive pulmonary disease or asthma. Am J Respir Crit Care Med 1996; 153: 530-534.

107. Seemungal TAR, Harper-Owen R, Bhowmilk A, Jeffries DJ, Wedzicha JA. Detection of rhinovirus in induced sputum at exacerbation of chronic obstructive pulmonary disease. Eur Respir J 2000; 16: 677-683.

108. Woolhouse IS, Bayley DL, Stockley RA. Sputum chemotactic activity in chronic obstructive pulmonary disease: effect of $a_{1}$-antitrypsin deficiency and the role of leukotriene $\mathrm{B}_{4}$ and interleukin 8. Thorax 2002; 57: 709-714.

109. Culpitt SV, Maziak W, Loukidis S, Nightingale JA, Matthews JL, Barnes PJ. Effect of high dose inhaled steroid on cells, cytokines and proteases in induced sputum in chronic obstructive pulmonary disease. Am J Respir Crit Care Med 1999; 160: 1635-1639.

110. Vignola AM, Roiccobono L, Mirabella A, et al. Sputum metalloproteinase-9/tissue inhibitor of metalloproteinase-1 ratio correlates with airflow obstruction in asthma and chronic bronchitis. Am J Respir Crit Care Med 1998; 158: 1945-1950.

111. Jayaram L, Parameswaran K, Sears MR, Hargreave FE. Induced sputum cell counts: their usefulness in clinical practice. Eur Respir J 2000; 16: 150-158.

112. Confalonieri M, Mainardi E, Della Porta R, et al. Inhaled corticosteroids reduce neutrophilic bronchial inflammation in patients with chronic obstructive pulmonary disease. Thorax 1998; 53: 583-585.
113. Culpitt SV, de Matos C, Russell RE, Donnelly LE, Rogers DF, Barnes PJ. Effect of theophylline on induced sputum inflammatory indices and neutrophil chemotaxis in chronic obstructive pulmonary disease. Am J Respir Crit Care Med 2002; 165: 1371-1376.

114. Hargreave FE, Leigh R. Induced sputum, eosinophilic bronchitis, and COPD. Am J Respir Crit Care Med 1999; 160: S53-S57.

115. Birring SS, Brighling CE, Bradding $\mathrm{P}$, et al. Clinical, radiologic and induced sputum features of chronic obstructive pulmonary disease in nonsmokers. Am J Respir Crit Care Med 2002; 166: 1078-1083.

116. Brightling CE, Pavord ID. Eosinophilic bronchitis - what is it and why is it important? Clin Exp Allergy 2000; 30: 4-6.

117. Gibson PG, Fujimura M, Niimi A. Eosinophilic bronchitis: clinical manifestations and implications for treatment. Thorax 2002; 57: 178-182.

118. Saetta M, Di Stefano A, Maestrelli P, et al. Airway eosinophilia in chronic bronchitis during exacerbations. Am J Respir Crit Care Med 1994; 150: 1646-1652.

119. Pavord ID, Brightling CD, Woltmann G, Wardlaw AJ. Non-eosinophilic corticosteroid unresponsive asthma. Lancet 1999; 353: 2213-2214.

120. Gibson PG, Hargreave FE, Grigis-Gabardo A, Morris MM, Denburg JA, Dolovich J. Chronic cough with eosinophilic bronchitis: examination for variable airflow obstruction and response to corticosteroid. Clin Exp Allergy 1995; 25: 127132.

121. Brightling CE, Ward R, Wardlaw AJ, Pavord ID. Airway inflammation, airway responsiveness and cough before and after inhaled budesonide in patients with eosinophilic bronchitis. Eur Respir J 2000; 15: 682-686.

122. Pizzichini MM, Pizzichini E, Efthimiadis A, et al. Sputum eosinophil and neutrophil proteins in smokers with severe chronic airflow limitation. Eur Respir J 1997; 10: Suppl. 25, $183 \mathrm{~s}$.

123. Keatings VM, Jatakanon A, Worsdell YM, Barnes PJ. Effects of inhaled and oral glucocorticoids on inflammatory indices in asthma and COPD. Am J Respir Crit Care Med 1997; 155: 542-548.

124. Gibson PG, Wooley KL, Carty K, Murree-Allen K, Saltos N. Induced sputum eosinophil cationic protein (ECP) measurement in asthma and chronic obstructive airway disease (COAD). Clin Exp Allergy 1998; 28: 1081-1088.

125. Louis RE, Cataldo D, Buckley MG, et al. Evidence of mastcell activation in a subset of patients with eosinophilic chronic obstructive pulmonary disease. Eur Respir J 2002; 20: $325-331$.

126. Metso T, Venge P, Haahtela T, Peterson CGB, Seveus L. Cell specific markers for eosinophils and neutrophils in sputum and bronchoalveolar lavage fluid of patients with respiratory conditions and healthy subjects. Thorax 2002; 57: 449-451.

127. Leigh R, Belda J, Kelly MM, et al. Eosinophil cationic protein relates to sputum neutrophil counts in healthy subjects. J Allergy Clin Immunol 2000; 106: 593-594.

128. Pizzichini MM, Pizzichini E, Efthimiadis A, et al. Asthma and natural colds: inflammatory indices in induced sputum: a feasibility study. Am J Respir Crit Care Med 1998; 158: 1178-1184.

129. Wark PA, Johnston SL, Moric I, Simpson JL, Hensley MJ, Gibson PG. Neutrophil degranulation and cell lysis is associated with clinical severity in virus-induced asthma. Eur Respir J 2002; 19: 68-75.

130. Marques LJ, Teschler H, Guzman J, Costabel U. Smoker's lung transplanted to a nonsmoker. Am J Respir Crit Care Med 1997; 156: 1700-1702.

131. Roby TJ, Swan GE, Sorenson KW, Hubbard GA, Schumann GB. Discriminant analysis of lower respiratory tract components associated wtih cigarette smoking, based on quantitative sputum cytology. Acta Cytol 1990; 34: 147154. 